\title{
Range expansion of the invasive Amazon sailfin catfish, Pterygoplichthys pardalis (Castelnau, 1855), in the central and southeastern Gulf of Mexico
}

\author{
Armando T. Wakida-Kusunoki ${ }^{1, *}$, Luis Enrique Amador-del Ángel ${ }^{2}$, Elizabeth \\ Romero-Hernandez ${ }^{3}$ and Lorenzo M. Bozada Robles ${ }^{4}$
}

${ }^{1}$ Instituto Nacional de Pesca, Centro Regional de Investigación Pesquera de Yucalpetén. Boulevard del Pescador S/N, esquina con antigua Carretera a Chelem. Puerto de Abrigo, Yucalpetén, Progreso, Yucatán. C.P. 97320.

${ }^{2}$ Universidad Autónoma del Carmen. Facultad de Ciencias Naturales, Centro de Investigación en Ciencias Ambientales CICA. Avenida Laguna de Términos s/n Colonia Renovación 2da Sección, C.P. 24155, Ciudad del Carmen, Campeche, México.

${ }^{3}$ Instituto Nacional de Pesca, Dirección General de Investigación Pesquera del Atlántico. Avenida Ejército Mexicano \# 106, Col. Ex hacienda Ylang Ylang, Boca del Río, Veracruz, México.

${ }^{4}$ Colegio Nacional de Estudios Profesionales CONALEP 058 Don Juan Osorio López. Km 9.5 Avenida Universidad, Colonia El Tesoro. C.P. 96536 Coatzacoalcos, Veracruz, México.

* Corresponding author: armandowakida@yahoo.com.mx

Received: 21/07/2015

Accepted: 02/05/2016

\begin{abstract}
Range expansion of the invasive Amazon sailfin catfish, Pterygoplichthys pardalis (Castelnau, 1855), in the central and southeastern Gulf of Mexico

Exotic armoured catfishes are known to be established in central and southeastern Mexico. We report the first record of the Amazon sailfin catfish, Pterygoplichthys pardalis, in Veracruz State, located on the eastern Gulf of Mexico. We captured one specimen in the Comejen River in La Florida, in March 2009, seven specimens in the Calzadas River tributary of the Coatzacoalcos River in May 2012, and three specimens in the Lagartos lagoon in Veracruz City (one in August 2012 and two in September 2013). Additional records from these regions indicate that $P$. pardalis is spreading in the Coatzacoalcos River basin and near Veracruz City. These records are indicative of the dispersion of this species in Mexico. Further sampling is required to assess the invasion area.
\end{abstract}

Key words: Pterygoplichthys pardalis, Amazon sailfin catfish, invasive species, Veracruz, Mexico.

\section{RESUMEN}

Extensión del rango del bagre armado invasor Pterygoplichthys pardalis (Calstelnau, 1855) en el centro y sureste del Golfo de México

Se conoce que el bagre armado exótico se ha establecido en el centro y el sureste de México. Reportamos el primer registro del bagre armado Pterygoplichthys pardalis en el estado de Veracruz localizado en el este del Golfo de México. Capturamos un espécimen en La Florida, Río Comején en Marzo de 2009, siete especímenes en el Río las Calzadas tributario del Río Coatzacoalcos en Mayo de 2012, y tres especímenes en la Laguna Lagartos en la ciudad de Veracruz (uno en Agosto de 2012 y dos en Septiembre de 2013). Registros adicionales en ambas regiones indican que P. pardalis se está extendiendo en la región de la cuenca del Río Coatzacoalcos y la Ciudad de Veracruz. Estos registros son indicativos de la dispersión de esta especie en México. Se requiere futuros muestreos para evaluar el área de invasión.

Palabras clave: Pterygoplichthys pardalis, bagre armado, especie invasora, Veracruz, México. 


\section{INTRODUCTION}

The exotic Amazon sailfin catfish, Pterygoplichthys pardalis, is native to the Amazon River basin (Peru, Bolivia and Brazil) (Weber, 1992; Page $\&$ Robins, 2006). As a result of the inadequate control of the pet fish trade, members of this family have been accidentally or intentionally introduced to some regions of the world (Hoover et al., 2004, Chavez et al., 2006, Page \& Robins, 2006), where they have successfully adapted.

In Mexico, the presence of the Amazon sailfin catfish was reported for the first time in the Mezcala River, Guerrero (Balsas basin), in 1995 (Guzmán \& Barragán, 1997) and later in Tecpatan, Chiapas, in the surroundings of Villahermosa, Tabasco (Mendoza-Alfaro et al., 2007), and in the Grijalva-Usumacinta basin (Tabasco and Chiapas) (Ramírez-Soberón et al., 2004, Wakida-Kusunoki et al., 2007; Wakida-Kusunoki \& Amador-del Ángel, 2008).

The first specimens were identified as Liposarcus multiradiatus, a synonym of Pterygoplichthys multiradiatus(Armbruster, 2004); however, the species is currently identified as $P$. pardalis and Pterygoplichthys disjunctivus (Wakida-Kusunoki \& Amador-del Ángel, 2008).

This paper describes the first records of the sailfin catfish in the state of Veracruz, Mexico.

\section{MATERIALS AND METHODS}

Four surveys to monitor the armoured catfish invasion were conducted in March 2009, May 2012, and in January and September 2013 in the

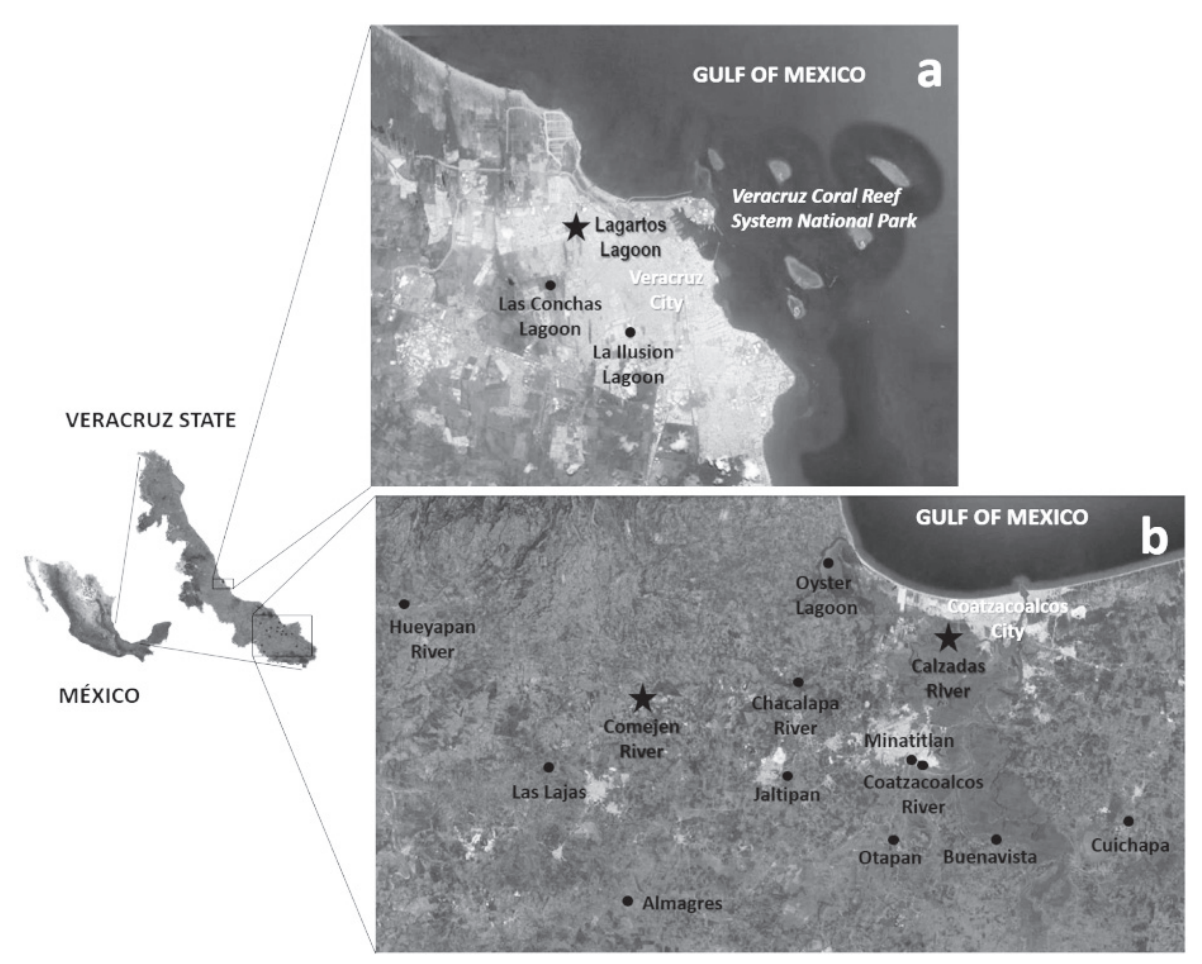

Figure 1. Recorded locations of Pterygoplichthys pardalis in Veracruz State, Mexico, showing a) Ramsar site no. 1450: Interdunes lagoon systems of Veracruz City and b) the Gulf Coastal Plain of southeastern Veracruz, Mexico: Coatzacoalcos River and its tributaries. Stars indicate the sites where $P$. pardalis was captured and circles indicate the multiple sites where this species was observed over the period from 2009 to 2013. Localidades de registro de Pterygoplichthys pardalis en el estado de Veracruz, México mostrando a) sistema de lagunas interdunarias de Veracruz, sitio Ramsar $n^{\circ} 1450$ y b) planicie costera del Golfo al suereste de Veracruz, México: Río Coatzacoalcos y sus tributarios. Las estrellas indican los sitios de captura de P. pardalis y los círculos indican los múltiples sitios donde se les ha visto en el período de 2009 a 2013. 
state of Veracruz, which is located on the Gulf of Mexico in the eastern to southeastern region of the Mexican Republic. The sampling sites are shown in Figure 1. Cast nets of $2.5 \mathrm{~m}$ in diameter with a mesh size of $76.2 \mathrm{~mm}$ were used during the survey.

The criteria used to identify the specimens were described by Weber (1992). The specimens were housed in the Ichthyology and Aquatic Invertebrate Collection of the Centro de Investigación de Ciencias Ambientales of the Universidad Autónoma del Carmen (CI-CICAUNACAR).

The two areas studied were a) the Coatzacoalcos River and its tributaries of the Gulf Coastal Plain in southern Veracruz (Fig. 1b) and b) the interdunes lagoon systems of Veracruz City within Ramsar site no. 1450 (Fig. 1a).

The Gulf Coastal Plain in southeastern Veracruz, Mexico: the Coatzacoalcos River and its tributaries. The Coatzacoalcos River at $18^{\circ} 8^{\prime} 56^{\prime \prime} \mathrm{N}$ and $94^{\circ} 24^{\prime} 41^{\prime \prime} \mathrm{W}$ is $325 \mathrm{~km}$ in length and has a total catchment area of $17.369 \mathrm{~km}^{2}$. Its course is fed by many rivers (Jaltepec River, Coachapa River, Uxpanapa River, Calzadas River) and streams (Teapa, Tepeyac, San Francisco) (Rosales-Hoz \& Carranza-Edwards, 1998). The area has a tropical rain climate (Am (i') $\mathrm{gw}^{\prime \prime}$ ) an average annual precipitation of $2780 \mathrm{~mm}$ and an average temperature of $24.5^{\circ} \mathrm{C}$. Three defined seasons occur in the region: from June to September, heavy rains occur in the catchment area; from October to February, strong winds from the north ("Nortes") are frequent; and from March to April, the hot season occurs, and saline waters can be detected $40 \mathrm{~km}$ upstream. A typical year sees more than 290 centimetres (110 in) of rainfall (García, 2004).

Ramsar site no. 1450: Interdunes lagoon systems of Veracruz City. This area is part of the system of coastal dunes that occurs in the central region of the state of Veracruz in Mexico at $19^{\circ} 16^{\prime}-19^{\circ} 06^{\prime} \mathrm{N}$ and $96^{\circ} 06^{\prime}-96^{\circ} 20^{\prime} \mathrm{W}$. The lagoons are in the periphery of the city of Veracruz towards its western side (Peralta-Peláez \& Moreno-Casasola, 2009). The area has a subhumid tropical climate with summer rains (Aw), an average annual precipitation of $1550 \mathrm{~mm}$ and an average temperature of $26^{\circ} \mathrm{C}$. During the wet season (June to October), the average monthly precipitation and temperature are $224( \pm 25) \mathrm{mm}$ and $30{ }^{\circ} \mathrm{C}( \pm 3.5)$, respectively, and during the dry season, the average monthly precipitation and temperature are $44( \pm 37) \mathrm{mm}$ and $22{ }^{\circ} \mathrm{C}( \pm 3)$, respectively (García, 2004).

\section{RESULTS}

The loricariid catfishes caught in Veracruz State had pigmentation with a geometric pattern on the head and leopard-like, dark spots of variable size on the abdomen (Fig. 2). The supraoccipital process was not elevated, and the orbits did not protrude above the top of the head. The posterior edge of the supraoccipital process was delimited by 3 scutes, and there were 2 scutes between the temporal and second predorsal scute. The number of scutes along the lateral line was 29 to 30 . The dorsal fin had one spine and 11 branched rays, the pectoral fin had one spine and 6 branched rays, and the pelvic fin had one spine and 5 branched rays (Fig. 2). We identified the suckermouth armoured catfish caught in Veracruz as the Amazon sailfin catfish, Pterygoplichthys pardalis (Castelnau, 1855).

On 14 March, 2009, two P. pardalis specimens of 305 and $401 \mathrm{~mm}$ of total length (TL) and weighing 259 and $406 \mathrm{~g}$ (catalogue numbers CICICA-UNACAR 0298 and 0299), respectively, were collected in the Comejen River (La Florida, Acayucán) $\left(18^{\circ} 2^{\prime} 49.16^{\prime \prime} \mathrm{N}, 94^{\circ} 51^{\prime} 24.55^{\prime \prime} \mathrm{O}, 54\right.$ m.a.s.l.) (Fig. 1). The substrate was rocky and muddy. The water surface temperature was $21^{\circ} \mathrm{C}$, and the salinity was $0.2 \mathrm{psu}$. The shoreline vegetation at the sampling site was primarily Typha domingensis, Thalia geniculata, Pontederia lanceolata, Cyperus giganteus, Eleocharis spp. and Sagittaria latifolia. The aquatic vegetation consisted of water hyacinth (Eichhornia crassipes), Salvinia minima, and Utricularia foliosa.

On 30 May, 2012, seven $P$. pardalis specimens of 279 to $357 \mathrm{~mm}$ TL and weighing 217 to $443 \mathrm{~g}$ (catalogue numbers CI-CICA-UNACAR 0310 to 0316) were collected in the Calzadas River, a tributary of the Coatzacoalcos River 
(18 $6^{\prime} 32.31^{\prime \prime} \mathrm{N}, 94^{\circ} 30^{\prime} 10.17^{\prime \prime} \mathrm{W}, 2$ m.a.s.1.) (Fig. 1a). In informal interviews with fishermen of the area, other invasion sites were identified such as the Coatzacoalcos River, the Chacalapa River, the Hueyapan River, Las Lajas, Minatitlán, Jaltipán, Almagres, Otapan, Buenavista and Oyster lagoon.

On 20 August, 2012, another two specimens of $P$. pardalis of 340 and $375 \mathrm{~mm}$ TL and weighing 320 and $335 \mathrm{~g}$ (catalogue numbers CI-CICAUNACAR 0338 and 0339), respectively, were captured in the Lagartos lagoon (1767 m perimeter, 18.59 ha in area) located at $19^{\circ} 12^{\prime} 24.40^{\prime \prime} \mathrm{N}$, $96^{\circ} 10^{\prime} 40.31^{\prime \prime} \mathrm{W}$, and 10 m.a.s.l. (Fig. 1b). The water surface temperature was $21^{\circ} \mathrm{C}$, and the salinity was $0.5 \mathrm{psu}$. In informal interviews with fishermen of the area, other invasion sites were identified as the La Ilusión lagoon and the Las Conchas lagoon. These lagoons are part of Ramsar site no. 1450: Interdunes lagoon systems of Veracruz City. These are rare geomorphologic
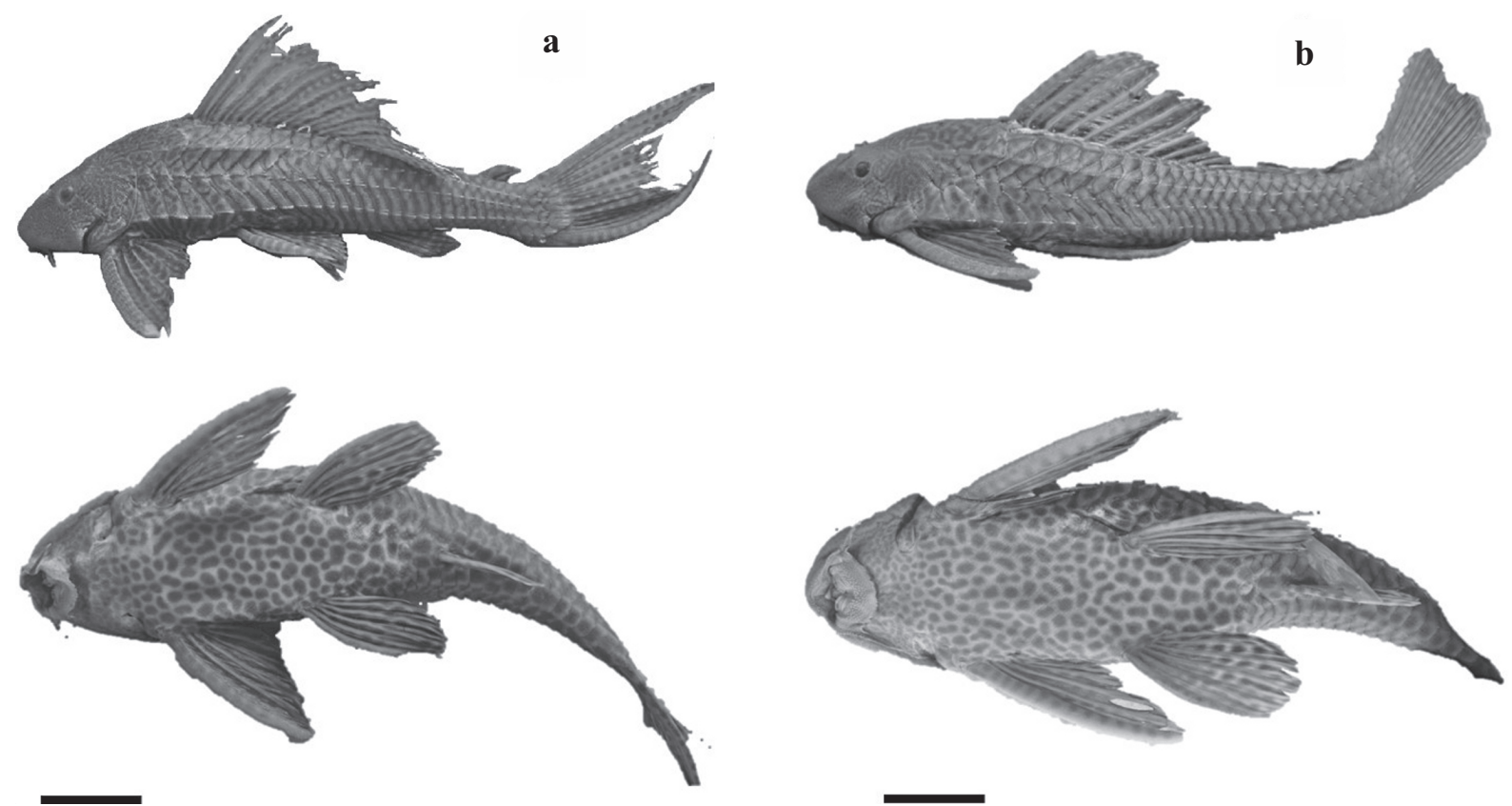

Figure 2. a) The lateral and ventral views of a male Pterygoplichthys pardalis (CI-CICA-UNACAR 0314), $340 \mathrm{~mm}$ TL, from the Calzadas River (a tributary of the Coatzacoalcos River), Veracruz, Mexico. b) The lateral and ventral views of a female Pterygoplichthys pardalis (CI-CICA-UNACAR 0340), $330 \mathrm{~mm}$ TL, from the Lagartos lagoon, Veracruz City, Veracruz, Mexico. Photograph by L.E. Amador-del Ángel. Bar = $50 \mathrm{~mm}$. a) Vista lateral y ventral de macho de Pterygoplichthys pardalis $340 \mathrm{~mm} L T$, (CI-CICA-UNACAR 0314) del Río las Calzadas un tributario del Río Coatzacoalcos, Veracruz, México. b) Vista lateral y ventral de hembra de Pterygoplichthys pardalis $330 \mathrm{~mm}$ LT, (CI-CICA-UNACAR 0340) de la Laguna Lagartos, ciudad de Veracruz, Veracruz, México. Fotografía de L.E. Amador-del Ángel. Barra $=50 \mathrm{~mm}$. features that have permanent water but depend entirely of rainfall recharging the aquifers. The shoreline vegetation at the sampling site was primarily Cyperus articulatus, Phyla nodiflora, Typha latifolia, and Pontederia sagittata.

On 13 September, 2013, another specimen of $P$. pardalis of $340 \mathrm{~mm}$ TL and weighing $315 \mathrm{~g}$ (catalogue numbers CI-CICA-UNACAR 0340) was captured in the Lagartos lagoon (Fig. 1b). The water surface temperature was $21^{\circ} \mathrm{C}$, and the salinity was $0.5 \mathrm{psu}$.

\section{DISCUSSION}

The $P$. pardalis expansion could have potentially undesirable effects in river and lagoon ecosystems. The documented ecological effects of $P$. pardalis include the disruption of the aquatic food chain, a decline in the abundance of native species, a reduction in tilapia, carp and freshwa-

.


ter prawn (Macrobrachium) fisheries, damage to fishing gear (especially cast and gill nets), the mortality of shore birds caused by choking, changes in aquatic plant communities, bank erosion and effects on water quality (e.g., increased turbidity) (Devick, 1989, Bunkley-Williams et al., 1994, Nico \& Martin, 2001, Hoover et al., 2004, Wakida-Kusunoki et al., 2007, Krishnakumar et al., 2009, Mendoza-Alfaro et al., 2009a, Nico et al., 2009).

In Veracruz, Mexico, the occurrence of P. pardalis in the interdunes lagoon systems of Veracruz City (Ramsar site no. 1450) is most likely the result of aquarium release or escape from aquaculture facilities during flood events.

The reports from fishermen at the end of 2008 regarding the capture of $P$. pardalis in the Coatzacoalcos River and its tributaries suggest that the dispersal of $P$. pardalis in the Coatzacoalcos River basin was most likely associated with severe flood events in southeastern Mexico (particularly in 2007), taking into account that natural events, such as tropical storms, hurricanes and typhoons, have been thought to facilitate their introduction into novel water systems in other parts of the world (Mendoza-Alfaro et al., 2009b).

It should be noted that at present, there is no direct association between the two collection areas.

These new reports indicate the continued dispersal of this fish species throughout the country of Mexico. Additional sampling and monitoring is necessary to evaluate the impacts of this new exotic species on the native fauna of freshwater ecosystems in Veracruz and to establish measures for their control and eradication.

\section{ACKNOWLEDGEMENTS}

We thank the following for various forms of assistance: Ing. Lina Abreu of Veracruz, Veracruz, and Ciro Antonio González of Acayucán, Veracruz, for providing valuable information. The comments of two referees significantly improved the quality of the manuscript.

\section{REFERENCES}

ARMBRUSTER, J. W. 2004. Phylogenetic relationships of the suckermouth armoured catfishes (Loricariidae) with emphasis on the Hypostominae and the Ancistrinae. Zoological Journal of the Linnean Society, 141: 1-80.

BUNKLEY-WILLIAMS, L., E. H. WILLIAMS JR, C. G. LILYSTROM, I. CORUJO-FLORES, A. J. ZERBI, C. ALIAUME \& T. N. CHURCHILL. 1994. The South American sailfin armored catfish, Liposarcus multiradiatus (Hancock), a new exotic established in Puerto Rican fresh waters. Caribbean Journal of Science, 30: 90-94.

CHAVEZ, J. M., R. M. DE LA PAZ, S. K. MANOHAR, R. C. PAGULAYAN \& J. R. CARANDANG. 2006. New Philippine record of South American sailfin catfishes (Pisces: Loricariidae). Zootaxa, 1109: 57-68.

DEVICK, W. S. 1989. Disturbance and fluctuations in the Wahiawa Reservoir ecosystem. Project F-14R-13, Job4, Study I. Hawaii Department of Land and Natural Resources, Division of Aquatic Resources, Honolulu.

GARCÍA, E. 2004. Modificaciones al sistema de clasificación climática de Köppen, 4th edn. Offset Larios, México.

GUZMÁN, A. F. \& S. J. BARRAGÁN. 1997. Presencia de bagres sudamericanos (Osteichthyes: Loricariidae) en el rio Mezcala, Guerrero, México. Vertebrata Mexicana, 3: 1-4.

HOOVER, J. J., K. J. KILlGORE \& A. F. COFRACESCO. 2004. Suckermouth catfishes: threat to aquatic ecosystem of the United States? Aquatic Nuisance Species Research Program Bulletin, 4: $1-9$.

KRISHNAKUMAR, K., R. RAGHAVAN, G. PRASAD, A. BIJUKUMAR, M. SEKHARAN, B. PEREIRA \& A. ALI. 2009. When pets become pests-exotic aquarium fishes and biological invasions in Kerala, India. Current Science, 97: 474-476.

MENDOZA ALFARO, R., S. CONTRERAS-BALDERAS, C. RAMÍREZ MARTÍNEZ, P. KOLEFF OSORIO, P. ÁLVAREZ TORRES \& V. AGUILAR SIERRA. 2007. Los peces diablo, especies invasoras de alto impacto. Biodiversitas, 70: $1-5$.

MENDOZA ALFARO, R., C. ESCALERA-GALLARDO, S. CONTRERAS-BALDERAS, P. KOLEFF OSORIO, C. RAMÍREZ MARTÍNEZ, P. 
ÁLVAREZ TORRES, M. ARROYO-DAMIÁN \& A. ORBE-MENDOZA. 2009a. Chapter 5. Invasion of Armored Catfish in Infiernillo Reservoir, Michoacán-Guerrero, Mexico, Socioeconomic Impact Analysis: A Tale of Two Invaders pp. 51-59 In: Mendoza-Alfaro R. E., B. Cudmore, R. Orr, J. P. Fisher, S. Contreras-Balderas, W. R. Courtenay, P. K. Osorio, N. Mandrak, P. Álvarez-Torres, M. Arroyo-Damián, C. Escalera-Gallardo, A. Guevara-Sanguines, G. Greene, D. Lee, A. OrbeMendoza, C. Ramírez-Martínez \& O. StrabridisArana (eds) Trinational risk assessment guidelines for aquatic alien invasive species: test cases for the snakeheads (Channidae) and armored catfishes (Loricariidae) in North American inland waters. Commission for Environmental Cooperation, Montreal, Canada.

MENDOZA ALFARO, R., J. P. FISHER, W. COURTENAY, C. RAMÍREZ MARTÍNEZ, A. ORBEMENDOZA, C. ESCALERA GALLARDO, P. ÁLVAREZ TORRES, P. KOLEFF OSORIO \& S. CONTRERAS BALDERAS. 2009b. Chapter 3. Armored Catfish (Loricariidae) Trinational Risk Assessment pp. 25-37. In: Mendoza-Alfaro R. E., B. Cudmore, R. Orr, J. P. Fisher, S. ContrerasBalderas, W. R. Courtenay, P. K. Osorio, N. Mandrak, P. Álvarez-Torres, M. Arroyo-Damián, C. Escalera-Gallardo, A. Guevara-Sanguines, G. Greene, D. Lee, A. Orbe-Mendoza, C. RamírezMartínez \& O. Strabridis-Arana (eds) Trinational risk assessment guidelines for aquatic alien invasive species: test cases for the snakeheads (Channidae) and armored catfishes (Loricariidae) in North American inland waters. Commission for Environmental Cooperation, Montreal, Canada.

NICO, L. G., H. L. JELKS \& T. TUTEN. 2009. Nonnative suckermouth armored catfishes in Florida: description of nest burrows and burrow colonies with assessment of shoreline conditions. Aquatic Nuisance Species Research Program Bulletin, 9:
$1-30$.

NICO, L. G. \& T. R. MARTIN. 2001. The South American suckermouth armored catfish, Pterygoplichthys anisitsi (Pisces: Loricariidae), in Texas, with comments on foreign fish introductions in the American Southwest. Southwestern Naturalist, 46: 98-104.

PAGE, L. M. \& R. ROBINS. 2006. Identification of sailfin catfishes (Teleostei: Locariidae) in Southeastern Asia. The Raffles Bulletin of Zoology, 54(2): 455-457.

PERALTA-PELÁEZ, L. A. \& P. MORENO-CASASOLA. 2009. Composición florística y diversidad de la vegetación de humedales en los lagos interdunarios de Veracruz. Boletín de la Sociedad Botánica de México, 85: 89-101.

RAMÍREZ-SOBERÓN, G., X. VALENCIA DÍAZ \& M. T. GASPAR-DILLANES. 2004. Nuevo record de bagres sudamericanos Liposarcus multiradiatus y L. spp. en las lagunas de Catazaja y Medellin, Chiapas. Resúmenes del IX Congreso Nacional de Ictiologia, Villahermosa.

ROSALES-HOZ, L. \& A. CARRANZA-EDWARDS. 1998. Heavy metals in sediments from Coatzacoalcos river, Mexico. Bulletin of Environmental Contamination and Toxicology, 60: 553-561.

WAKIDA-KUSUNOKI, A. T., R. RUIZ-CARUS \& L. E. AMADOR-DEL ÁNGEL. 2007. Amazon sailfin catfish, Pterygoplichthys pardalis (Castelnau, 1855) (Loricariidae) another exotic species established in Southeastern Mexico. The Southwestern Naturalist, 52(1): 141-144.

WAKIDA-KUSUNOKI, A. T. \& L. E. AMADORDEL ÁNGEL. 2008. Nuevos registros de los plecos Pterygoplichthys pardalis (Castelnau, 1855) y $P$. disjunctivus (Weber 1991) en el Sureste de México. Hidrobiológica, 18: 251-255.

WEBER, C. 1992. Révision du genre Pterygoplichthys sensu lato (Pisces, Siluriformes, Loricariidae). Revue française d'aquariologie, 19: 1-36. 